\title{
DIRECT LYSIS GLASS MILK METHOD OF GENOMIC DNA EXTRACTION REVEALS GREATER ARCHAEAL DIVERSITY IN ANAEROBIC BIODIGESTER SLURRY AS ASSESSED THROUGH DENATURING GRADIENT GEL ELECTROPHORESIS
}

\author{
P. Verma, V. Vasudevan\#, B. K. Kashyap, T. I. Samsudeen, M. K. Meghvansi, \\ D. V. Kamboj*, L. Singh
}

Biotechnology Division, Defence Research \& Development Establishment, Gwalior - 474 002, Madhya Pradesh, India

Received - December 27, 2017; Revision - April 13, 2018; Accepted - April 21, 2018

Available Online - April 25, 2018

DOI: http://dx.doi.org/10.18006/2018.6(2).315.323

KEYWORDS
Biodigester
PCR-DGGE
16S rRNA
Archaeal diversity
extraction

\begin{abstract}
DNA extraction from anaerobic biodigester slurry is a critical step in all phylogenetic and metagenomic approaches to characterize highly diverse biodigester ecosystem, but little is known about the efficiency of different extraction procedures and their impact on subsequent analyses of microbial communities. The assessment of performance differences, therefore, is a concrete step towards the determination of optimal DNA extraction method for biodigester slurry, which can provide a more reliable comparison of the metaanalysis results obtained in different conditions. Here, we report a highly efficient direct lysis genomic DNA extraction method (Glass milk method) from the slurry of an anaerobic biodigester. This method was compared with five commercially available DNA extraction kits and two different manual methods with regard to DNA extraction, purification efficiencies and representation of archaeal diversity through PCRDenaturing Gradient Gel Electrophoresis (DGGE). Results revealed that commercial kits yielded significantly lower DNA concentrations than manual methods. Moreover, interpretations of bacterial community structure based on analysis of PCR-DGGE banding pattern of 16S rRNA gene, ShannonWiener and Simpson's indices of diversity and multidimensional scaling suggested that manual methods of DNA isolation revealed far greater archaeal diversity as compared to the commercial kits. Further, in realtime PCR analysis, a methanogens-specific 16S rRNA gene concentration was observed more in manual methods than in commercial kits. The glass milk DNA extraction method proposed here is very useful in pursuing phylogenetic and metagenomic approaches to characterize the highly complex anaerobic biodigester ecosystem with greater reliability and precision.
\end{abstract}

\#Present address: Defence Food Research Laboratory, Mysuru, 570011, Karnataka, India *Corresponding author e-mail: kamboj_dev@drde.drdo.in (D. V. Kamboj)

Peer review under responsibility of Journal of Experimental Biology and Agricultural Sciences.

Production and Hosting by Horizon Publisher India [HPI] (http://www.horizonpublisherindia.in/).

All rights reserved.
All the article published by Journal of Experimental Biology and Agricultural Sciences is licensed under a Creative Commons Attribution-NonCommercial 4.0 International License Based on a work at www.jebas.org.

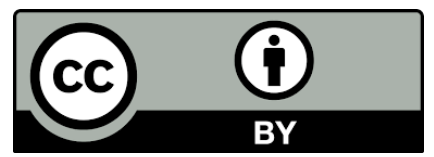




\section{Introduction}

Microbial degradation of organic matter occurring in the absence of molecular oxygen, has been harnessed as one of the most effective methods of waste decomposition and renewable-energy production. During this process, bacteria degrade macromolecules such as carbohydrates, lipids and proteins into short chain fatty acids, hydrogen and carbon dioxide that are subsequently utilized by the archaea to produce methane, carbon dioxide and small amounts of other gases through a sequential process involving four main reactions: hydrolysis, acidogenesis, acetogenesis and methanogenesis. Methanogens are classified in Archaeal phylum Euryarchaeota (Solli et al., 2014), and methane is produced as the terminal step of the anaerobic process. The methanogenic microbes that usually dominate in biogas reactors belong to acetoclastic group (Zinder, 1993). Worldwide, a great deal of anaerobic digesters have been built with varying capacity ranging from large mechanized systems that operate at constant temperatures to smaller family and community digesters that have no provisions for temperature control (Nand, 1999). It is estimated that there are about 30 million anaerobic biodigesters of smallscale in Asia and Latin America that are of different type such as ambient temperature fixed-dome, floating dome type and Taiwanese model (Huttunen \& Lampinen, 2005; Lansing et al., 2008). Defence Research \& Development Establishment, Gwalior (India) has developed a technology for biodegradation of human waste using cold-active anaerobic microbial inoculum (AMI). The performance of biotoilets based on this biodigester technology has been demonstrated in different areas of high altitude, plains as well as on mobile platforms such as passenger coaches in Indian Railways.

Composition of the microbial community in a biogas digester directly determines its efficiency and biogas yield. The complex interactions between bacterial and archaeal microbiome dictate the performance of an anaerobic digester to a considerable extent, which are greatly influenced by environmental factors. The information on microbial community dynamics in anaerobic digester can provide newer insights in microbiology which may be useful for improving the design and performance of new generation biodigesters. Therefore, study of microbial community dynamics during the process of biodegradation of organic matter in biodigester is one of the crucial aspects concerning the monitoring of biodigester performance. In past, diverse culturebased as well as molecular methods have been recruited for gaining information on taxonomy and phylogeny of microbial communities of anaerobic biodigesters by various researchers (Vanwonterghem et al., 2014; Ziganshina et al., 2014). Similarly, culture-independent approaches such as Denaturing Gradient Gel Electrophoresis (DGGE) have also been used extensively in characterization of the complex microbial community. Although there has been a rapid development in high-throughput and inexpensive sequence analyses, nevertheless, DGGE still continues to serve as an important component of analyses of microbial communities (Green et al., 2010). According to Muyzer et al. (1993), DGGE profiles of the V3 region was simpler and relatively cost-effective for analysing the structural variation between different microbial systems or the spatio-temporal dynamics of the same system as compared to the sequencing analysis of $16 \mathrm{~S}$ rDNA genes in clone libraries. It could also be useful in tracing the variation of dominant microbial organism in a biogas digester. PCR/DGGE strategies are in vogue for the purpose of characterization of the microbial communities, and evaluation of the time required for adaptation of the granular inoculum to the conditions in the anaerobic reactors fed with manure (Bergland et al., 2015).

Nucleic acid extraction is the first step for any metagenomic study of microbial community dynamics. In anaerobic microbial system, microbial cells remain tightly bound to the substrate, and high levels of humic contamination poses particular challenges in terms of getting required quality and quantity of DNA that can be amplified through PCR for the purpose of analysis of microbial community (Qiao et al., 2013). During DNA isolation from activated sludge, it is difficult to achieve complete cell lysis owing to heavy encapsulation of microorganisms (McIllroy \& Porter, 2010). Many researchers, therefore, have highlighted the importance of optimizations of extraction procedures, taking into account cell-lysis efficiency and recovery of DNA for getting information on size or structure of microbial community (Lipp et al, 2008; Morono et al., 2014). It has also been emphasized that suitable modifications in prevailing protocols are often imperative in case of the samples having low densities of microbial population or having high adsorptive properties, or complex matrices (Alain et al., 2011; Nielsen et al., 2014). Commercially available kits may be useful for nucleic acid extraction from conventional samples. Nevertheless, for meeting specific extraction requirements of complex samples like those of anaerobic digesters, such kits may not yield desired results. Another bottleneck is that kits may not be available at commercial level for unconventional uses for which only a limited number of scientists are interested (Ogram et al., 1987; Corinaldesi et al., 2005). According to Weaver (2013), susceptibility level of microbes to chemical lysis procedures tends to differ. The Grampositive bacteria have cell walls with thicker layers of peptidoglycan in comparison to that of Gram-negative bacteria. Therefore, the procedures used in DNA extraction may be prejudiced toward isolating DNA from certain types of microbes only thereby making it a challenging aspect to isolate DNA that correctly represents the diversity of microbes in the sampled community (Weaver, 2013). These challenges underpin the relevance of tailor-made extraction methods to selected realms of 
nucleic acid based research despite the extra effort on the part of preparing the appropriate reagents and more time-intensive protocols for extraction (Alain et al., 2011; Morono et al., 2014; Alawi et al., 2014).

Although considerable efforts have been made to study on DNA extraction from soil or composting, nevertheless, DNA extraction approaches for complex anaerobic microbial consortium are still limited. As a consequence of this lack of progress, DNA extraction remains a major bottleneck in the process of analyzing large number of samples from anaerobic digesters. Considering the above-mentioned challenges, the present study aimed to provide an improved direct lysis method (Glass milk method) for genomic DNA extraction of archaeal community from the slurry of an anaerobic biodigester, through optimization of extraction procedures and comparison with commercially available five DNA extraction kits and other two manual methods.

\section{Materials and Methods}

\subsection{Operation of Experimental Biodigester}

The experimental biodigester of $2 \mathrm{~L}$ working volume was seeded with $30 \%$ of the cold active AMI that contained specially adapted consortium of bacteria belonging to four different groups namely hydrolytic, acidogenic, acetogenic and methanogenic bacteria. The biodigester was fed in semi-continuous mode at 10 days of hydraulic retention time (HRT) with a configuration of $100 \mathrm{~g}$ of night soil mixed with $100 \mathrm{ml}$ of tap water and operated under mesophilic conditions. The bioreactor was constantly stirred before the evacuation of waste and after feeding. Slurry samples for microbial DNA extraction were taken in stabilized phase of biodigester. Methane content in biogas was measured every day using a Thermo ULTRA gas chromatography (Singh et al., 1995). The determination of chemical oxygen demand (COD) was performed according to the standard protocol (APHA, 2005).

\subsection{DNA extraction using commercial kits}

To study the community structure and population dynamics during degradation of night soil in anaerobic biodigester, DNA recovery using five commercial kits and three manual methods was compared. The kits evaluated in this study were selected to represent commercially available DNA extraction methodologies, the use of which has been reported in literature. Five commercially available DNA extraction kits, i.e., ZR Soil Microbe DNA Kit (ZR), Power Soil DNA Isolation Kit (PS), Ultra Clean Fecal DNA Kit (UCF), Ultra Clean Soil DNA Isolation Kit (UCS), Qiagen Stool DNA Kit (QS) were evaluated in this study. To compare the five extraction kits for their efficiency to recover DNA from biodigester slurry, extractions were performed in triplicate according to the manufacturers' instructions. Comparison of various extraction methods and approach followed is provided in Table 1.

Table 1 Comparison of various DNA extraction methods

\begin{tabular}{|c|c|}
\hline $\begin{array}{l}\text { DNA } \\
\text { extraction } \\
\text { method }\end{array}$ & Approach followed* \\
\hline $\mathrm{ZR}$ & Bead beating purification by spin filter columns \\
\hline PS & $\begin{array}{l}\text { Bead beating purification by spin filter columns; } \\
\text { Kit intended for use with samples containing } \\
\text { high humic acid }\end{array}$ \\
\hline UCF & $\begin{array}{l}\text { Bead beating purification by spin filter columns; } \\
\text { Kit intended for DNA isolation from feces }\end{array}$ \\
\hline UCS & Bead beating purification by spin filter columns \\
\hline QS & $\begin{array}{l}\text { Bead beating purification by spin filter columns; } \\
\text { Kit intended for DNA isolation from feces }\end{array}$ \\
\hline MM1 & $\begin{array}{l}\text { Freeze thawing in liquid nitrogen in presence of } \\
\text { SDS; CTAB purification }\end{array}$ \\
\hline MM2 & $\begin{array}{l}\text { Freeze thawing in liquid nitrogen in presence of } \\
\text { SDS; PEG } 4000 \text { purification }\end{array}$ \\
\hline MM3 & $\begin{array}{l}\text { Freeze thawing in liquid } \mathrm{N} 2 \text { in presence of SDS; } \\
\text { Adsorption to silica followed by DNA } \\
\text { precipitation with Isopropanol }\end{array}$ \\
\hline \multicolumn{2}{|c|}{$\begin{array}{l}\text { *For consistency, each resultant DNA extract sample was } \\
\text { suspended in } 100 \mu \text { lof the eluant solution. }\end{array}$} \\
\hline \multicolumn{2}{|c|}{$\begin{array}{l}\text { ZR, Zymo Research Kit; PS, Power Soil Kit; UCF, Ultra Clean } \\
\text { Fecal DNA Kit; UCS, Ultra Clean Soil DNA Kit; QS, Qiagen Stool } \\
\text { Kit; MM1, Manual Method 1; MM2, Manual Method 2; MM3, } \\
\text { Manual Method 3. }\end{array}$} \\
\hline
\end{tabular}

\subsection{DNA extraction using Manual methods}

\subsubsection{Direct lysis and purification method}

Direct lysis of microbial cells was carried out employing combination of physical and chemical methods (freeze thawing in liquid nitrogen in presence of anionic detergent, Sodium Dodecyl Sulphate). DNA was extracted using the method suggested by Yeates et al. (1997) and purified subsequently with CTAB (Manual Method 1, MM1) and PEG 4000 (Manual Method 2, MM2). 


\subsubsection{Glass milk method (Manual Method 3, MM3)}

\subsubsection{Desorption of microbial cells}

Biodigester slurry $(1 \mathrm{ml})$ was washed twice with $0.85 \% \mathrm{NaCl}$ and pellet was resuspended in phosphate buffered saline solution containing $0.15 \%$ Tween 80 . The suspension was vortexed for 15 min and the feed material was pelleted using low speed centrifugation (500 x $g$ for 30 seconds at room temperature). Supernatant fractions were recovered and transferred to sterile tubes followed by centrifugation at $10000 \mathrm{x} \mathrm{g}$ for $20 \mathrm{~min}$ at room temperature. The pelleted material was used for further DNA extraction.

\subsubsection{Glass milk preparation}

Silicon dioxide ( $5 \mathrm{~g}$ ), of 0.5-10 $\mu \mathrm{m}$ diameter obtained from Sigma, USA, was suspended in $50 \mathrm{ml}$ of water and centrifuged at $2000 \mathrm{x}$ $g$ for $5 \mathrm{~min}$. The supernatant was discarded and resuspended in 50 $\mathrm{ml}$ of water. The $\mathrm{pH}$ was adjusted to 6.8 with conc. $\mathrm{HCl}$. The sediment was left for $2 \mathrm{~h}$ allowing precipitation of silica and then supernatant was discarded. The sedimentation procedure was repeated twice followed by centrifugation at $3000 \mathrm{x} g$ for $5 \mathrm{~min}$. Residual water was removed with pipette and the silica pellet was resuspended in $30 \mathrm{ml}$ of $3 \mathrm{M}$ guanidine isothiocyanate. Using a wide bore or cut-off tip, $1.5 \mathrm{ml}$ of slurry was taken in a $2-\mathrm{ml}$ eppendorf vial containing the Zirconium glass beads (Biospec Products Inc) and spinned at $14000 \mathrm{x} \mathrm{g}$ for $5 \mathrm{~min}$ in a microcentrifuge. The supernatant was discarded and the pellet was resuspended in $1 \mathrm{ml}$ cell lysis buffer, $100 \mu \mathrm{l}$ of $3 \mathrm{M}$ potassium acetate solution and $100 \mu 1 \mathrm{H}_{2} \mathrm{O}$. The sample was frozen in liquid nitrogen and thawed in water at room temperature followed by vigorous vortexing for $2 \mathrm{~min}$. This step was repeated twice. It was spinned at $4{ }^{\circ} \mathrm{C}$ for $15 \mathrm{~min}$ at $14000 \times \mathrm{g}$. Supernatant $(300 \mu \mathrm{l})$ was transferred to fresh tube along with $600 \mu \mathrm{l}$ of glass milk and mixed by continuous shaking on rotating table for 5 min followed by centrifugation at $14000 \times \mathrm{x}$ for $1 \mathrm{~min}$. Supernatant was discarded and the pellet was washed with $500 \mu \mathrm{l}$ of ice-chilled ethanol (70\%) followed by centrifugation at $10000 \mathrm{x} g$ for $1 \mathrm{~min}$. To remove any residual ethanol, final spinning was done for 20 seconds. DNA was eluted from matrix by adding $110 \mu \mathrm{l}$ of nuclease free $\mathrm{H}_{2} \mathrm{O}$ to the pellet, vortexing and final spinning at $12000 \times \mathrm{x}$ for $1 \mathrm{~min}$. Supernatant $(100 \mu \mathrm{l})$ containing genomic DNA was collected in a sterilized tube (IAEA, 2004). The genomic DNA, so isolated, was checked for its quality, purity and concentration as described below.

\subsubsection{DNA quantification and Agarose gel electrophoresis}

The genomic DNA was quantified by ND- 1000 spectrophotometer (Nanodrop, Thermoscientific, USA). The purity of DNA was checked by the absorption ratio at 260/280 nm and at $260 \mathrm{~nm} / 230 \mathrm{~nm}$. The integrity of the extracted genomic DNA was tested by $0.8 \%$ agarose gel electrophoresis.

\subsection{PCR-DGGE Analysis}

The PCR mixture for each sample contained $25 \mathrm{ng}$ of template DNA (final concentration of $1 \mathrm{ng} / \mu \mathrm{l}$ ), $200 \mu \mathrm{M}$ of each dNTP, 2.5 $\mathrm{mM} \mathrm{MgCl}_{2}, 1 \mathrm{X}$ PCR buffer, and $1 \mathrm{U}$ of Taq DNA polymerase (Fermentas) as well as $0.5 \mu \mathrm{M}$ of primers designed to amplify the V3 region of rrs gene from either bacteria or from archaea. Primers used in the study were: $16 \mathrm{~S} 1$ GAGTTTGATCCTGGTCA $\left.3^{\prime}\right)$ and $16 \mathrm{~S} 2$ ACGGCTACCTTGTTACGACTT 3') as suggested by Lane (1991) and Arc344F (5' ACG GGG YGC AGC AGG CGC GA 3') and Arc519R (5' GWA TTA CCG CGG CKG CTG 3') as suggested by $\mathrm{Yu}$ and coworkers (2008). A touch down PCR protocol was employed, consisting of an initial denaturation step at $95^{\circ} \mathrm{C}$ for $5 \mathrm{~min}$, followed by 20 cycles of $95^{\circ} \mathrm{C}$ for 60 seconds, $65^{\circ} \mathrm{C}$ to $55^{\circ} \mathrm{C}$ for 30 seconds (Decrease of $0.5^{\circ} \mathrm{C}$ per cycle) then consistent annealing temperature of $55^{\circ} \mathrm{C}$ for 15 cycles and $72^{\circ} \mathrm{C}$ for 60 seconds; and a final extension step at $72^{\circ} \mathrm{C}$ for $10 \mathrm{~min}$. PCR product $(25 \mu \mathrm{l})$ was subjected to DGGE using an $8 \%(w / v)$ polyacrylamide gel with a $30-65 \%$ denaturing gradient for $5 \mathrm{~h}$ at $150 \mathrm{~V}$ in a DCode Universal Mutation Detection System (BioRad). Gels were stained with 1x SYBR Green solution (Invitrogen) and visualized using Fluorchem 20, Alpha Innotech.

\subsection{DGGE banding pattern analysis}

DGGE banding patterns were analyzed using GelCompar® II v6.5 software (Applied Maths, Belgium). Bands were normalized following the conversion of scanned gels. A reference position was defined to align the banding patterns after the bands were associated with the standard for proper comparison. A Kolmogorov-Smirnov nonparametric test of the equality of continuous, one-dimensional probability distributions was performed to compare the given sample with a reference probability distribution. Similarity values among the banding patterns were calculated on the basis of comparison of the corresponding bands using the Dice similarity coefficient. The band matching tolerance and optimization were set at $0.50 \%$. Dendrograms were calculated using UPGMA (unweighted-pair group method using arithmetic averages) clustering algorithm with branch quality set at cophenetic correlation. Further, the statistical analysis of the data on relative archaeal diversity (as estimated through DGGE profiling of various DNA samples obtained through different extraction procedures) was conducted using GelCompar ${ }^{\circledR}$ II v6.5 software employing following methods: 


\subsubsection{Shannon-Wiener and Simpson's indices of diversity}

Using GelCompar ${ }^{\circledR}$ II v6.5 software, the Shannon-Wiener and Simpson's indices of diversity were calculated, taking into account the diversity (i.e., number of categories present in the sampled population), as well as the equitability (i.e., the evenness of the distribution of entries over the different categories (Anonymous, 2010). For a sampled population of $N$ entries belonging to $K$ categories, the Shannon-Wiener index $(\mathrm{H})$ of diversity was calculated as follows:

$$
H=-\sum_{i=1}^{K} \frac{n_{i}}{N} \cdot \ln \left(\frac{n_{i}}{N}\right)
$$

where $n_{i}$ is the number of entries in category $i$.

Simpson's index of diversity is defined as the probability that two consecutive entries will belong to different categories. Given $K$ categories present in a sampled pouplation of $N$ entries, the probability of sampling category $i$ twice consecutively is as follows:

$$
P_{i}=\frac{n_{i}\left(n_{i}-1\right)}{N(N-1)}
$$

where $n_{i}$ is the number of entries in category $i$.

Here, the probability $(\mathrm{P})$ of any two samples of the same category is given by:

$$
P=\sum_{i=1}^{K} P_{i}
$$

Hence, Simpson's index of diversity $(D)$ will be $D=1-P$.

\subsubsection{Multi-dimensional scaling (MDS)}

Using GelCompar ${ }^{\circledR}$ II v6.5 software, MDS was carried out based on the Euclidean distance between two entry points according to the following formula:

$$
d_{i j}=\sqrt{\sum_{k=1}^{p}\left(x_{i k}-x_{j k}\right)^{2}}
$$

where $\mathrm{p}$ is the number of dimensions, $\mathrm{d}_{\mathrm{ij}}$ is the distance, and $\mathrm{x}_{\mathrm{ik}}$ is the data value of the $\mathrm{i}^{\text {th }}$ row and $\mathrm{k}^{\text {th }}$ column.

\subsection{Statistical Analysis}

Means and standard deviations of the data pertaining to DNA concentration and purity ratios (i.e., 260/280 and 260/230) were calculated using Microsoft Excel 2007 (Microsoft Corporation, Redmond, WA, USA). Differences between mean values of various parameters viz., DNA concentration and absorbance ratios were compared through Analysis of Variance (ANOVA) followed by Least Significant Difference (LSD) Post-Hoc test. P value $<0.05$ was considered statistically significant. SPSS Statistics 17.0 program was used for calculating ANOVA and LSD. Accordingly, statistically significant differences among mean values have been shown with different letters on the columns in Figures 1 and 2.

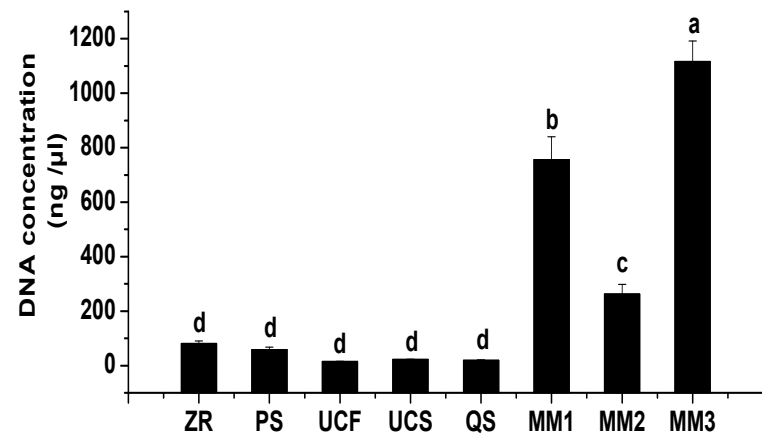

Figure 1 DNA yield (ng $/ \mu 1)$ in samples obtained through various methods. Error bar shows standard deviation of mean $(n=3)$. Columns without common letter differ significantly at LSD $P \leq 0.05$. For acronyms, refer Table 1 .

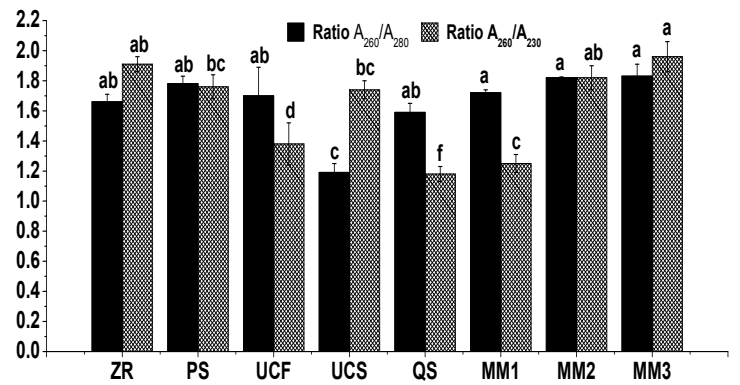

Figure 2 DNA purity in terms of absorbance ratios $\left(\mathrm{A}_{260} / \mathrm{A}_{280}\right.$ and $\left.\mathrm{A}_{260} / \mathrm{A}_{230}\right)$ of DNA samples obtained through various methods. Error bar shows standard deviation of mean $(n=3)$. Columns without common letter differ significantly at LSD $P \leq 0.05$. For acronyms, refer Table 1.

\section{Results and Discussion}

\subsection{Biodigester performance}

Lab-scale experimental Biodigester (2L) operated in fed-batch mode at 10 day-HRT showed the $\mathrm{pH}$ value varying between 7 and 8 during the operational period. The COD removal efficiency was recorded as $78 \%$, and methane content in biogas was found $62 \%$ during the operational period. The effluent concentrations of 
COD, and associated methane yield represented the efficient organic removal and stable process operation (Data not shown) as reported earlier (Singh et al., 1993).

\subsection{DNA yield and purity}

In current study, the DNA yield (Figure 1) and purity (Figure 2) varied with different extraction methods. Significantly higher DNA yield was obtained in the case of glass milk method (MM3) followed by CTAB purification (MM1) and PEG 4000 purification (MM2) methods (Figure 1) with observed values being $1116.16 \mathrm{ng} / \mu 1,755.83 \mathrm{ng} / \mu \mathrm{l}$ and $262.30 \mathrm{ng} / \mu 1$, respectively. On the contrary, commercially available kits provided very poor yield with no statistically significant difference in DNA concentration amongst them (Figure 1). The DNA yield obtained using commercial kits ranged from $14.43 \mathrm{ng} / \mu \mathrm{l}$ to $80.43 \mathrm{ng} / \mu \mathrm{l}$.

Several studies have compared extraction methods and reported that they differ in their ability to recover DNA, indicating that no single DNA extraction method is optimal for all kind of samples (Whitehouse \& Hottel, 2007; Queipo-Ortuno et al., 2008; Vesty et al., 2017) thereby necessitating further efforts to develop more efficient methods catering to specific requirements. Each method prescribed has advantages and disadvantages rendering the selection of a suitable method a daunting task. The extraction of DNA from sludge samples in anaerobic digesters has rarely been studied or optimized, so there is a lack of standardized methods (Dong et al., 2013). Our findings also unequivocally strengthen the view that the overall quality and yield of genomic DNA is influenced by DNA extraction approach. According to Yeates and coworkers (1997), absorbance ratio of $A_{260}$ to $A_{280}(>1.7)$ and $A_{260}$ to $A_{230}(>2.0)$ is indicative of pure DNA. In the present study, purity of DNA obtained using the glass milk method (MM3) was found to be the best among all the methods as evident from maximum values of 1.83 and 1.96 for ratios of $A_{260}$ to $A_{280}$ and $A_{260}$ to $A_{230}$, respectively (Figure 2). Purity of extracted DNA using other kits (ZR, UCS and QS) was not appreciable as evident from low absorbance ratio $\left(\mathrm{A}_{260}\right.$ to $\left.\mathrm{A}_{280}\right)$ ranging from 1.19 to 1.70 indicating presence of absorbing contaminants, possibly the humic acids (Li et al., 2004; Shamia et al., 2017), in the preparations. Purity of DNA in terms of ratio of $\mathrm{A}_{260}$ to $\mathrm{A}_{230}$ was also found to be significantly high for the glass milk method (MM3) in comparison to other methods.

The majority of nucleic acid extraction recipes are prepared keeping in view the complete lysis of cells and subsequent extraction of intracellular nucleic acids into aqueous solution, the elimination of organic and inorganic molecules (non-nucleic acid) from the aqueous extracts, and the minimization of product losses during the course of purification (Lever et al., 2015). The yield and quality of cellular and bacterial DNA extracts re variably affected by the cell lysis methodology (Sohrabi et al., 2016). The protocol of glass milk method was also designed keeping these aspects in view. Here, the efficient cell lysis was achieved through optimal degree of freeze-thawing and bead beating. Following cell disruption, the nucleolytic degradation was effectively inhibited using guanidine isothiocyanate as reported earlier (Lippke et al., 1987). This was followed by precipitation of SDS-bound proteins using potassium acetate to allow their removal from DNA. In a similar study, highly efficient cell lysis from the samples of anaerobic digestion sludge employed for the evaluation of effectiveness of DNA extraction provided DNA recovery efficiency as high as $86.16 \%$ (Dong et al., 2013). SDS is known to aid in lysing cells and solubilizing proteins. In addition, $\mathrm{K}^{+}$-SDS interactions have been utilized in past for protein and DNA analysis studies (Li et al., 1989; Hejazi et al., 2013). Taken together, the extraction yield of PCR-ready DNA was greater in glass milk method (MM3) as compared to other two manual methods and five commercial kits indicating its potential utility and advantage for downstream molecular biological processes for studying microbial communities of anaerobic digester.

\subsection{PCR-DGGE profiling}

PCR product of the 1492 bp size was obtained for universal 16S primers following thermal amplification. In order to reveal the metagenomic attributes of the extracted DNA, nested PCR was performed on amplicons obtained with universal 16S primers. Many studies have employed DGGE profiles of the $\mathrm{V} 3$ regions in order to reflect the dominant community structure and to analyse the structural variation between different systems or the dynamics of the same system (Yu et al., 2008; Liu et al., 2009; Bergland et al., 2015). In the current study, the primers for V3 hyper variable regions of $16 \mathrm{~S}$ rRNA gene generated the band of $\sim 176$ bp in agarose gel electrophoresis. Furthermore, the PCR-DGGE profile indicated wide variation in archaeal diversity in the samples obtained through various approaches of DNA extraction with maximum diversity being observed with respect to glass milk method (Figure 3). Quantitative measurement of diversity in a community can be reflected by calculating Shannon-Wiener and Simpson's indices of diversity which are among the most commonly used indices. These indices represent as to how evenly the basic entities (such as archaeal species) are distributed in the sampled community. In the current study, the pattern of diversity was further confirmed based on comparative values of ShannonWiener and Simpson's indices of diversity (Figure 4A \& 4B) with maximum diversity observed for the glass milk method. In addition, optimized three-dimensional representation of similarity matrix calculated based on Euclidean distance for various samples employing MDS technique also indicated greater archaeal diversity in respect of glass milk method (Figure 5). Consistent with present findings, recent studies have also brought to light the 

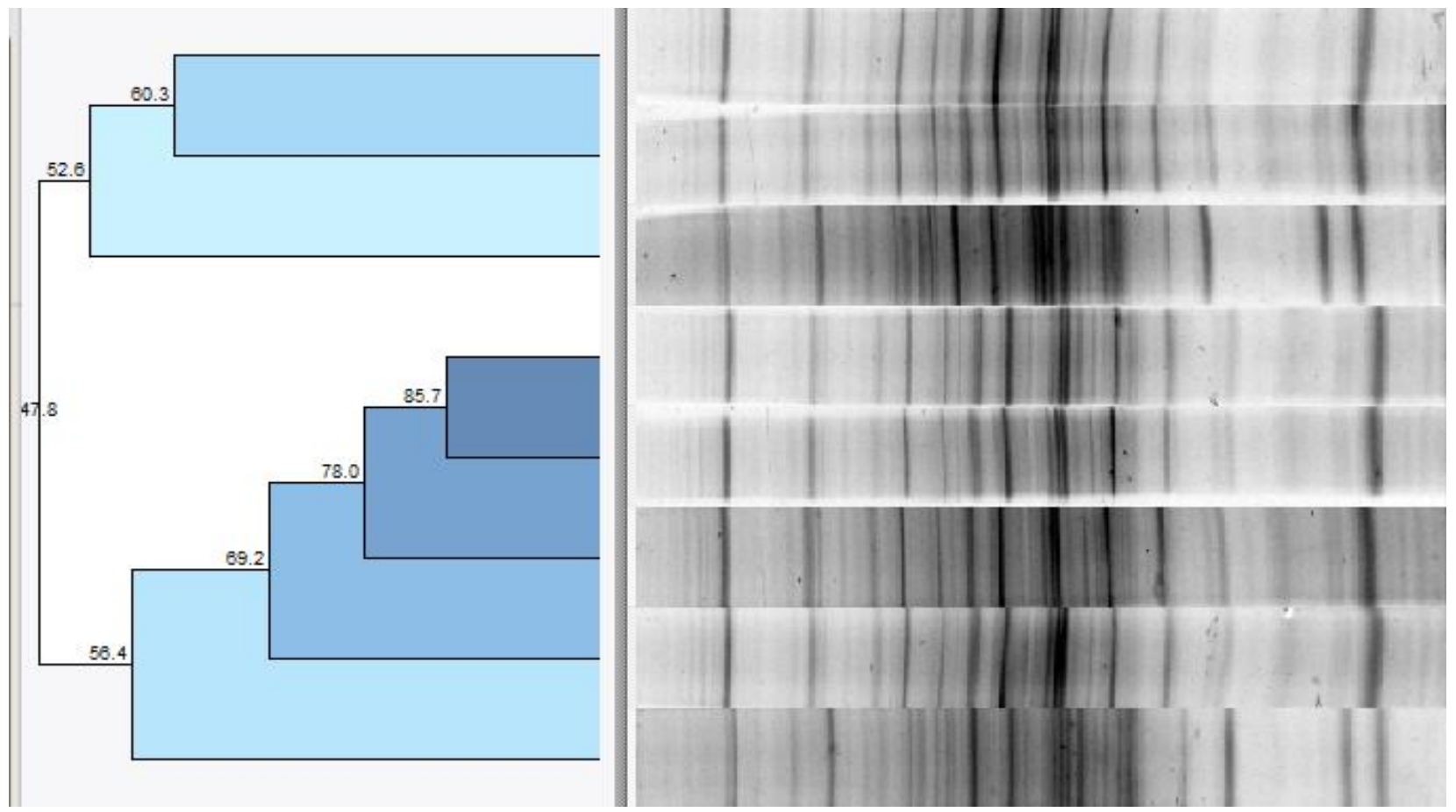

Figure 3 Comparison of archaeal community in biodigester slurry represented through V3-amplified (rrs gene) DGGE profiles of DNA extracted employing eight different methods. An unweighted-pairgroup method using arithmetic averages (UPGMA)-based dendrogram is also shown in left hand panel. Clustering was done based on comparison of the corresponding bands using the Dice similarity coefficient. Bootstrap values

(\%) are shown at branch-points. Samples in different lanes from top to bottom were in the following order: ZR; MM2; MM3; UCF; QS; MM1; PS; UCS. For acronyms, refer Table 1.

(A)

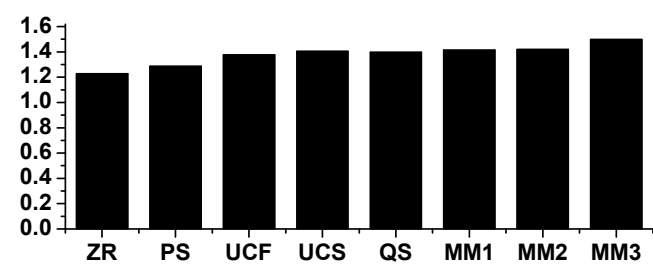

(B)

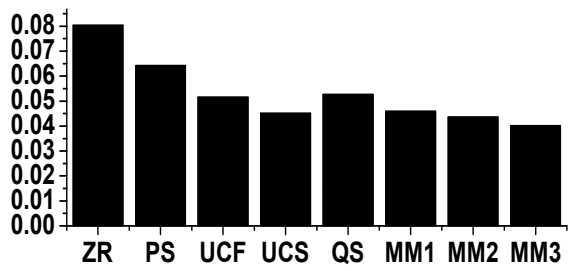

Figure 4 Comparative Shannon-Wiener (A) and Simpson's indices (B) of diversity of archaeal community in biodigester slurry as represented through V3-amplified (rrs gene) DGGE profiles of DNA extracted employing eight different methods.

instances wherein the choice of cell lysis method used during DNA extraction was found to impact the recovery of specific bacterial phyla. Mechanical lysis was reported to increase the number of different bacterial phyla recovered from saliva (Lazarevic et al., 2013), while the addition of lysozyme to mechanical lysis improves overall bacterial DNA yield from saliva (Sohrabi et al., 2013).
Overall, the glass milk method described here provided high quality DNA even without the use of column purification that can be successfully amplified by PCR. In addition, greater recovery of archaea from the test samples as established through PCR-DGGE profiling indicates the suitability of this method for studying the phylogenetic community composition and functionality in complex communities present in anaerobic biodigester slurry. 


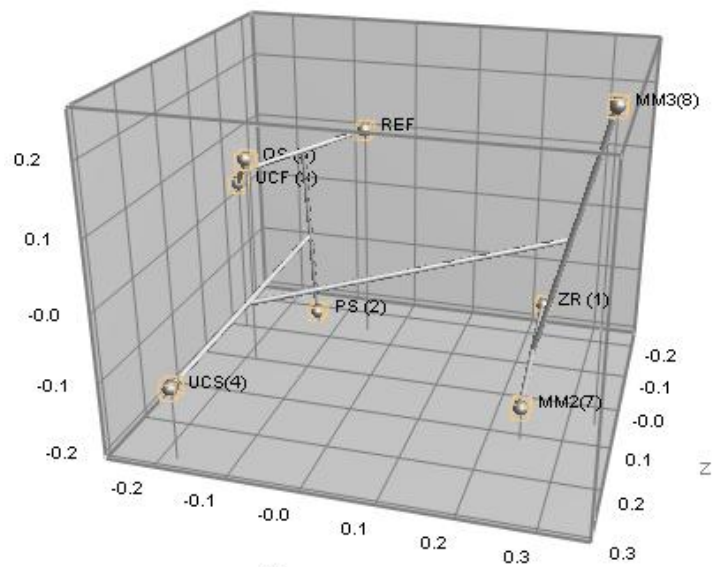

Figure 5 Optimized three-dimensional representation of similarity matrix of archaeal diversity calculated based on Euclidean distance for various samples employing MDS technique.

\section{Acknowledgement}

We thank Director, DRDE Gwalior, Madhya Pradesh, India for providing all laboratory facilities and support required for conducting this study.

\section{Conflict of Interest}

Authors would hereby like to declare that there is no conflict of interests that could possibly arise

\section{References:}

Alain K, Callac N, Ciobanu MC, Reynaud Y, Duthoit F, Jebbar M (2011) DNA extractions from sub seafloor sediments: novel cryogenic-mill- based procedure and comparison to existing protocols. Journal of Microbiological Methods 87: 355-362.

Alawi M, Schneider B, Kallmeyer J (2014) A procedure for separate recovery of extra-and intracellular DNA from a single marine sediment sample. Journal of Microbiological Methods 104: 36-42.

Anonymous (2010) Gel Compar II Manual version 6.5. Applied Maths, Belgium. Pp. 429.

APHA (2005) American Public Health Association. Standard methods for the examination for water and wastewater. $20^{\text {th }}$ ed., AWWA, WPCF, Washington, D.C., USA, Pp. 5.14-5.19.

Bergland WH, Dinamarca C, Toradzadegan M, Nordgård ASR, Bakke I, Bakke R (2015) High rate manure supernatant digestion. Water Research 76: 1-9.
Corinaldesi C, Danovaro R, Dell'Anno A (2005) Simultaneous recovery of extracellular and intracellular DNA suitable for molecular studies from marine sediments. Applied and Environmental Microbiology 71: 46-50.

Dong B, Yi J, Dai L, Dai X (2013) Evaluation of several DNA extraction methods for obtaining total community DNA from anaerobic digestion sludge. Procedia Environmental Science 18: 856-863.

Green SJ, Leigh MB, Neufeld JD (2010) Denaturing Gradient Gel Electrophoresis (DGGE) for microbial community analysis. In: Timmis KN (Ed.), Handbook of Hydrocarbon and Lipid Microbiology. Springer-Verlag, Heidelberg, Pp. 4137-4158.

Hejazi SM, Erfan M, Mortazavi SA (2013) Precipitation Reaction of SDS and Potassium Salts in Flocculation of a Micronized Megestrol Acetate Suspension. Iranian Journal of Pharmaceutical Research 12 : 239-246.

Huttunen S, Lampinen A (2005) Bioenergy Technology Evaluation and Potential in Costa Rica; University of Jyväskylä Printing House, Jyväskylä, Finland.

IAEA (2004) qPCR workshop for Rumen microbial ecology. International Atomic Energy Agency, Australia Pp 1 - 38.

Lane DT (1991) 16S / 23S rRNA sequencing. In: Nucleic acid techniques in bacterial systematics. In: Stackebrandt E, Goodfellow M (Eds.), John Wiley, New York, USA, Pp 115-175.

Lansing S, Botero R, Martin JF (2008) Waste treatment and biogas quality in small-scale agricultural digesters. Bioresource Technology 99: 5881-5890.

Lazarevic V, Gaïa N, Girard M, FrancËois P, Schrenzel J (2013) Comparison of DNA extraction methods in analysis of salivary bacterial communities. PLoS One 8: e67699.

Lever MA, Torti A, Eickenbusch P, Michaud AB, Šantl-Temkiv T, Jørgensen BB (2015) A modular method for the extraction of DNA and RNA, and the separation of DNA pools from diverse environmental sample types. Frontiers in Microbiology 6: 476.

Li JKK, Johnson T, Yang YY, Shore V (1989) Selective separation of virus proteins and double-stranded RNAs by SDS$\mathrm{KCl}$ precipitation. Journal of Virological Methods 26: 3-16.

Li H, Li Y, Zou S, Li C (2004) Extracting humic acids from digested sludge by alkaline treatment and ultrafiltration. Journal of Material Cycles and Waste Management 16: 93-100.

Lipp JS, Morono Y, Inagaki F, Hinrichs KU (2008) Significant contribution of Archaea to extant biomass in marine subsurface sediments. Nature 454: 991-994. 
Lippke JA, Strzempko MN, Raia FF, Simon SL, French CK (1987) Isolation of intact high-molecular-weight DNA by using guanidine isothiocyanate. Applied and Environmental Microbiology $53: 2588-2589$.

Liu FH, Wang SB, Zhang JS, Zhang J, Yan X, Zhou HK, Zhao GP, Zhou ZH (2009) The structure of the bacterial and archaeal community in a biogas digester as revealed by denaturing gradient gel electrophoresis and 16S rDNA sequencing analysis. Journal of Applied Microbiology 106: 952-966.

McIllroy S, Porter K (2010) DNA and RNA extraction. In: Seviour R, Nielson PH (Eds.), Microbial Ecology of Activated Sludge. IWA Publishing, London, Pp. 343-349.

Morono Y, Terada T, Hoshino T, Inagaki F (2014) Hot-alkaline DNA extraction method for deep-subsea floor archaealc ommunities. Applied and Environmental Microbiology 80: 19851994.

Muyzer G, De Waal EC, Uitterlinden AG (1993) Profiling of complex microbialpopulations by denaturing gradient gel electrophoresis analysis of polymerasechain reaction-amplified genes coding for 16S rRNA. Applied and Environmental Microbiology 59: 695-700.

Nand K (1999) Biomethanation from Agro-Industrial and Food Processing Wastes. In: Joshi VK, Pandey A (Eds.), Biotechnology: Food Fermentation Microbiology, Biochemistry and Technology. Educational Publishers and Distributers: Kerala, India, Pp. 1349-1372.

Nielsen MB, Kjeldsen KU, Lever MA, Ingvorsen K (2014) Survival of prokaryotes in a polluted waste dump during remediation by alkaline hydrolysis. Ecotoxicology 23: 404-418.

Ogram A, Sayler GS, Barkay T (1987) The extraction and purification of microbial DNA from sediments. Journal of Microbiological Methods 7: 57-66.

Qiao J, Guo R, Shi X, Qiu Y (2013) Evaluation of DNA extraction and purification methods for corn straw biogas slurry. Advanced Materials Research 773: 113-117.

Queipo-Ortuno MI, Tena F, Colmenero JD, Morata P (2008) Comparison of seven commercial DNA extraction kits for the recovery of Brucella DNA from spiked human serum samples using real time PCR. European Journal of Clinical Microbiology \& Infectious Diseases 27: 109-114.

Shamia IS, Halabi MN, El-Ashgar NM (2017) Humic acid determination in some compost and fertilizer samples. IUG Journal of Natural Studies 25: 42-50.

Singh L, Maurya MS, Ramana KV, Alam SI (1995) Production of biogas from night soil at psychrophilic temperature. Bioresource Technology 53: 147-149.

Singh L, Maurya MS, Sai Ram M, Alam SI (1993) Biogas production from night soil - Effects of loading and temperature. Bioresource Technology 45: 59-61.

Sohrabi M, Nair RG, Samaranayake LP, Zhang L, Zulfiker AHM, Ahmetagic A, Good D, Wei MQ (2016) The yield and quality of cellular and bacterial DNA extracts from human oral rinse samples are variably affected by the cell lysis methodology. Journal of Microbiological Methods 122: 64-72.

Solli L, Håvelsrud OE, Horn SJ, Rike AG (2014) A metagenomic study of the microbial communities in four parallel biogas reactors. Biotechnology for Biofuels 7: 146.

Vanwonterghem I, Jensen PD, Ho DP, Batstone DJ, Tyson GW (2014) Linking microbial community structure, interactions and function in anaerobic digesters using new molecular techniques. Current Opinion in Biotechnology 27: 55-64.

Vesty A, Biswas K, Taylor MW, Gear K, Douglas RG (2017) Evaluating the impact of DNA extraction method on the representation of human oral bacterial and fungal communities. PLOS One 12: e0169877.

Weaver J (2013) DNA Extraction: Overcoming Obstacles in Microbial Studies. Biotechqniques. http://www.biotechniques.com/news/DNA-Extraction-

Overcoming-Obstacles-in-Microbial-Studies/biotechniques335698.html (accessed 19 May 2017).

Whitehouse CA, Hottel HE (2007) Comparison of five commercial DNA extraction kits for the recovery of Franciella tularensis DNA from spiked soil samples. Molecular and Cellular Probes 21: 92-96.

Yeates C, Gillings MR, Davison AD, Altavilla N, Veal DA (1997) PCR amplification of crude microbial DNA extracted from soil. Letters in Applied Microbiology 25: 303-307.

Yu Z, Garcia Gonzalez R, Schanbacher FL, Morrison M (2008) Evaluations of different hypervariable regions of Archaeal 16S rRNA genes in profiling of methanogens by Archaea specific PCR and denaturing gradient gel electrophoresis. Applied and Environmental Microbiology 74: 889-893.

Ziganshina EE, Bagmanova AR, Khilyas IV, Ziganshin AM (2014) Assessment of a biogas-generating microbial community in a pilot-scale anaerobic reactor. Journal of Bioscience and Bioengineering 117: 730-736.

Zinder SH (1993) Physiological ecology of methanogenesis. In: Ferry JG (Ed.), Methanogenesis. Ecology, Physiology, Biochemistry and Genetics. Chapman \& Hall, USA, Pp. 128-206. 